\title{
Effect of Selected Alternative Fuels and Raw Materials on the Cement Clinker Quality
}

\author{
Július Strigáč \\ Považská cementáreň a.s. Ladce \\ e-mail: strigac.j@pcla.sk
}

\begin{abstract}
The article deals with the study of the effects of alternative fuels and raw materials on the cement clinker quality. The clinker quality was expressed by the content of two principal minerals alite $\mathrm{C}_{3} \mathrm{~S}$ and belite $\mathrm{C}_{2} \mathrm{~S}$. The additions of alternative fuels ashes and raw materials, in principle, always increased the belite content and conversely reduced the amount of alite. The alternative fuels with high ash content were used such as the meatbone meal, sewage sludge from sewage treatment plants and paper sludge and the used alternative raw materials were metallurgical slags - granulated blastfurnace slag, air cooled blastfurnace slag and demetallized steel slag, fluidized bed combustion fly ash and waste glass. Meat-bone meal, sewage sludge from sewage treatment plants and paper sludge were evaluated as moderately suitable alternative fuels which can be added in the amounts of 2.8 wt. \% addition of meat-bone meals ash, $3.64 \mathrm{wt}$. \% addition of sewage sludge ash and $3.8 \mathrm{wt} . \%$ addition of paper sludge ash to the cement raw mixture. Demetallised steel slag is suitable for production of special sulphate resistant cement clinker for CEM I -SR cement with addition up to $5 \mathrm{wt}$. \%. Granulated blastfurnace slag is a suitable alternative raw material with addition $4 \mathrm{wt}$. \%. Air cooled blastfurnace slag is a suitable alternative raw material with addition $4.2 \mathrm{wt}$. \%. Waste glass is not very appropriate alternative raw material with addition only 1.16 wt. \%. Fluidized bed combustion fly ash appears not to be equally appropriate alternative raw material for cement clinker burning with less potential utilization in the cement industry and with addition $3.41 \mathrm{wt}$. \%, which forms undesired anhydrite $\mathrm{CaSO}_{4}$ in the cement clinker.
\end{abstract}

Key words: alternative fuels, alternative raw materials, clinker quality

\section{Introduction}

The growth of alternative fuels and raw materials utilization in the cement industry has been enormous in the recent decade [1-3]. The reason is accompanied with economic as well as environmental aspects. Environmental aspects consist in the effort of saving depletable fossil fuels and nature raw materials, decreasing $\mathrm{CO}_{2}$ emissions and waste deposits, saving landfill space and supporting at environmental pollution reduction. The worldwide annual production of cement is responsible for about $5 \%$ of the total $\mathrm{CO}_{2}$ emission [4]. However, the use of biofuels or alternative fuels with some biomass content can decrease $\mathrm{CO}_{2}$ emissions due to the 
fact, that the biomass is $\mathrm{CO}_{2}$ neutral, since it is utilized for the growth of next biomass [5]. Economic aspects are connected with creating added value by substituting expensive fossil fuels with the cheaper or cost-less secondary fuels and the cost-less or negative cost wastes. The same effect is also reached by reducing exploitation of quarry raw materials by replacing with secondary raw materials or wastes.

The cement production enables an energy and materials recovery and waste disposal in a great extent. Unbeatable and unique advantages of the burning of alternative fuels and wastes in the cement rotary kilns are as follows: high combustion temperatures about $2000{ }^{\circ} \mathrm{C}$ in the main flame and $1400-1500{ }^{\circ} \mathrm{C}$ of the burned clinker and guaranteed oxidizing atmosphere during firing, sufficiently long retention time of fired substrates in the areas with high temperatures, non-waste incineration of organic substrates without producing ash, since forming ashes are immediately built in the creating clinker structure being fired, utilization of the heat and material content of organic substrates and saving fossil fuels, formation of nontoxic combustion gases $\mathrm{CO}_{2}, \mathrm{NO}_{\mathrm{X}}, \mathrm{H}_{2} \mathrm{O}, \mathrm{O}_{2}$ without a possibility of backward formation of harmful halogenated organic compounds containing dioxins and furans, acidic gases such as $\mathrm{HCl}, \mathrm{HF}$ and $\mathrm{SO}_{\mathrm{X}}$ are highly captured by alkaline preheated and precalcinated raw mixture with high content of free lime $\mathrm{CaO}$ [6]. The alternative fuels commonly used in the cement industry are as follows [2, 3]: solid - used tyres, rubber wastes, plastics, textile, thermal fraction of domestic, municipal and industrial wastes, sewage sludge from wastewater plants, animal meals (rendering plant by-product), as well as solid biofuels such as contaminated wood, by-products from wood treatment, paper sludge, paper, cardboard etc.; liquid - waste oils, spent solvents, waste paints, distillation residues, animal fat etc.; gaseous - pyrolysis gas, landfill gas, gas from anaerobic digestion of sewage sludge from wastewater plants etc. From the given kinds of alternative fuels, only solid alternative fuels (SAF) contain ash in such amount, that they can affect the mineralogical composition of clinker and so the cement quality. The standard EN 15357 [7] defines SAF as solid recovered fuel prepared from nonhazardous waste to be utilized for energy recovery in incineration or coincineration plants and meeting the classification and specification requirements laid down in EN 15359 [8]. The standard EN 15359 [8] introduces the new classification system for SAF, which classifies them into 5 qualitative classes according to 3 basic classification characteristic values such as net calorific value, chlorine and mercury content. The standard EN ISO 16559 [9] defines solid biofuels including waste demolition wood arising from demolition of buildings or civil engineering installations. The new classification system for solid biofuels is introduced by standard EN ISO 17225-1 [10].

The alternative raw materials (ARM) usually utilized in the cement industry are as follows [2]: metallurgical slags, wastes from metal industry, siliceous and calcareous fly ashes, circulating fluidized bed combustion fly and bottom ashes, spent foundry sand, construction and demolition debris, carbide lime, contaminated soil, red and brown mud, roasted pyrite cinder, gypsum from gas desulphurization, chemical gypsum etc.

The limitations for using SAF and ARM are fulfilling the emission limits during their burning, their maximal contents of pollutants such as heavy metals, halogenated organic compounds (PAHs, PCBs etc.) and the presence of problematic chlorine, sulphur, sodium and potassium compounds. The restrictions are given by laws, regulations and directives [11, 12]. Any kind of SAF and ARM has an impact on the burning conditions during firing of the clinker and the quality of clinker, its microstructure and product properties [13, 14]. 
The SAF and ARM affect the raw mixture composition, its reactivity and burnability. Each element possesses own influence on clinker composition and properties [13, 14]. Sodium $\mathrm{Na}$, commonly occurring element in SAF, with higher amounts in meat-bone meal (MBM), has effect on setting behaviour, causes the formation of orthorhombic $\mathrm{C}_{3} \mathrm{~A}$ instead of cubic $\mathrm{C}_{3} \mathrm{~A}$ or alkali sulphate according to the degree of sulphatisation of clinker. The amount of reactive orthorhombic $\mathrm{C}_{3} \mathrm{~A}$ decreases with increasing sulphatisation in clinker. Potassium $\mathrm{K}$, also commonly occurring element in alternative fuels, has very similar effect on the cement quality as sodium. Generally, alkali $\mathrm{Na}$ and $\mathrm{K}$ promote higher early strength and lower long term strength. High levels of alkali are not required because they can cause alkali-silica reaction in the concretes containing aggregates with alkali sensitive constituents.

Sulphur S is volatile, forms alkali sulphates which influence setting behaviour. Sulphur in alite causes the growth of enlarged crystals. Chlorine $\mathrm{Cl}$ is volatile, forms alkali chlorides, which are formed sooner than alkali sulphates and so influences the degree of clinker sulphatisation. After evaporating chlorine and sulphur, they form cycles in the kiln system atmosphere, raise the undesired coating layers, build-ups and rings. They support an agglomeration of large clinker nodules. High levels of chlorides are not required, because they promote the concrete and reinforcing steel chloride-induced corrosion. Fluorine $\mathrm{F}$ mainly in gypsum from neutralization of acidic solutions used for polishing lead crystal glass, lowers melting point, increases $\mathrm{C}_{3} \mathrm{~S}$ formation, up to $0.5 \%$ increases early strength, then has retarding effect. Aluminium Al mainly from food aluminum foils, wrappers and packets increases the amount of interstitial mass, promotes higher clinker reactivity, increases strength development. Iron $\mathrm{Fe}$ at local reducing burning conditions is subject to the reduction of $\mathrm{Fe}^{3+}$ to $\mathrm{Fe}^{2+} . \mathrm{Fe}^{2+}$ in contrast to $\mathrm{Fe}^{3+}$ is compatible with alite structure and can be incorporated into alite. The subsequent oxidation of $\mathrm{Fe}^{2+}$ in alite structure under oxidizing conditions causes decomposition of alite to belite and free lime and so the loss of strength and a possible effect on soundness. This effect causes less $\mathrm{C}_{4} \mathrm{AF}$ formation and more $\mathrm{C}_{3} \mathrm{~A}$ and affects the setting behaviour, because the settnig is faster. Phosphate $\mathrm{P}$ mainly from MBM or sewage sludge stabilizes $\mathrm{C}_{2} \mathrm{~S}$ and so causes the decrease of $\mathrm{C}_{3} \mathrm{~S}$ amount, retards the strength development, which has adverse effect on the cement quality. Higher amounts of phosphate lead to the formation of solid solution $\mathrm{C}_{2} \mathrm{~S}-\mathrm{C}_{3} \mathrm{P}$ with the crystal structure of $\beta-\mathrm{C}_{2} \mathrm{~S}, \alpha^{\prime}-\mathrm{C}_{2} \mathrm{~S}$ and $\alpha-\mathrm{C}_{2} \mathrm{~S}$, moreover the last modification has no hydraulic properties. The content of $\mathrm{P}_{2} \mathrm{O}_{5}$ is the main limitation factor for the increasing of $\mathrm{MBM}$ cofiring $[15,16]$. The belite $\mathrm{C}_{2} \mathrm{~S}$ content increasing connected with alite $\mathrm{C}_{3} \mathrm{~S}$ decreasing every time means the decrease of early strengths and hydration heat development, but the increase in chemical durability. American standard ASTM C 150 [17] designates the Portland cement with mineralogical composition containing up to $35 \mathrm{wt}$. $\%$ of $\mathrm{C}_{2} \mathrm{~S}$ and up to $45 \mathrm{wt} . \%$ of $\mathrm{C}_{3} \mathrm{~S}$ as the Type IV: portland cement having a low heat of hydration, while Portland cement for general use, which is known also as ordinary Type I, can contain up to $30 \mathrm{wt} . \%$ of $\mathrm{C}_{2} \mathrm{~S}$ and up to $65 \mathrm{wt} . \%$ of $\mathrm{C}_{3} \mathrm{~S}$ [17].

The aim of the article is the evaluation of effect of SAF and ARM on the clinker phase composition resulting from belite content increasing and so to interpret the suitability and amount of SAF and ARM for clinker production without any quality loss. 


\section{Materials and methods}

A common industrial cement raw mixture (RM) with chemical composition given in Table 1 and was used for the laboratory burnings. In order to prevent the influence of random large particles, the original RM was additionally ground to pass the aperture size of the sieve of 0.2 $\mathrm{mm}$, with maximum $1 \%$ residue and thoroughly homogenized. Then the effect of RM granulometry on the clinker phases forming rate was studied at constant temperature of 1430 ${ }^{\circ} \mathrm{C}$ and on two RMs with different granulometries. The reference was industrial raw mixture with maximum $1 \%$ residue on a $90 \mu \mathrm{m}$ sieve and the laboratory prepared one with granulometry of maximum $1 \%$ residue on $200 \mu \mathrm{m}$ sieve. The effect of selected SAF and ARM on the clinker phases formation was performed by means of the calcined SAF ashes and by dried ARMs. MBM ash was prepared under laboratory conditions by MBM thermal treatment at $650{ }^{\circ} \mathrm{C}$ for 1 hour in an oxidizing atmosphere in laboratory kiln and the ash of sewage sludge from waste water plants and ash of paper sludge were calcinated at $800{ }^{\circ} \mathrm{C}$ for 1 hour. Their chemical composition is given in Table 1 as well, and the mineralogical composition is described down. The calcined ashes as well as dried raw materials were spread in agate mortar to very fine powder (with fineness more than $400 \mathrm{~m}^{2} / \mathrm{kg}$ ). After the fine ashes and dried ARMs adding into RM up to maximal 5 wt. \% (at MBM ash maximal 8 wt. \%), the experimental mixtures were mixed and then thoroughly homogenized, which ensured the homogeneity of the experimental mixtures without presence of local differences in the concentration.

Table 1: The chemical composition of the used common industrial cement raw mixture (RM), the ashes of alternative fuels such as (ash of meat-bone meal (AMBM), ash of sewage sludge from waste water plants (ASS), ash of paper sludge (APS)) and the alternative materials (granulated blastfurnace slag (GBS), air cooled blast-furnace slag (ABS), demetallized steel slag (DSS), fluidized bed combustion fly ash (FCFA), waste glass (WG)).

\begin{tabular}{|c|c|c|c|c|c|c|c|c|c|c|c|}
\hline wt. \% & $\mathrm{SiO}_{2}$ & $\mathrm{Al}_{2} \mathrm{O}_{3}$ & $\mathrm{Fe}_{2} \mathrm{O}_{3}$ & $\mathrm{CaO}$ & $\mathrm{MgO}$ & $\mathrm{P}_{2} \mathrm{O}_{5}$ & $\mathrm{Na}_{2} \mathrm{O}$ & $\mathrm{K}_{2} \mathrm{O}$ & $\mathrm{SO}_{3}$ & $\mathrm{Cl}^{-}$ & L.o.I. \\
\hline RM & 14.73 & 3.14 & 1.92 & 43.03 & 1.04 & 0.06 & 0.19 & 0.69 & 0.36 & 0.02 & 34.80 \\
AMBM & 1.56 & 0.15 & 0.69 & 45.89 & 1.52 & 34.40 & 3.39 & 3.09 & 0.86 & 2.86 & 5.52 \\
ASS & 42.06 & 17.08 & 5.62 & 20.30 & 1.62 & 5.64 & 0.28 & 0.42 & 4.79 & 0.72 & 0.89 \\
APS & 24.51 & 14.13 & 0.79 & 57.09 & 3.45 & 0.22 & 0.08 & 0.63 & 0.78 & 0.26 & 0.02 \\
GBS & 42.17 & 6.87 & 0.32 & 41.92 & 10.39 & 0.05 & 0.17 & 0.60 & 1.84 & 0.02 & 0.95 \\
ABS & 40.57 & 8.12 & 2.81 & 41.73 & 8.44 & 0.14 & 0.19 & 0.72 & 2.39 & 0.01 & 0.09 \\
DSS & 12.81 & 1.64 & 29.78 & 52.30 & 2.54 & 0.48 & 0.07 & 0.04 & 0.28 & 0.01 & 6.02 \\
FCFA & 40.99 & 21.24 & 7.80 & 25.86 & 3.22 & 0.76 & 0.31 & 0.99 & 9.07 & 0.02 & 3.11 \\
WG & 75.58 & 0.33 & 0.21 & 6.73 & 4.23 & 0.03 & 14.66 & 0.61 & 0.46 & 0.04 & 0.01 \\
\hline
\end{tabular}

Cylindrical pellets were pressed out from the mixtures to the constant volume weight 2.6 g.cm ${ }^{-3}$ and the size $10 \mathrm{~mm}$ diameter x $20 \mathrm{~mm}$ height. The pellets were burnt in a specially modified laboratory kiln with a sliding manipulator containing platinum holder for samples. 4 cylindrical pellets were pressed out from each mixture. Manipulator of the specially modified kiln moved the pellet in to the centre of the kiln firing zone having been preheated to $1430{ }^{\circ} \mathrm{C}$, and after the lapse of burning time, the clinker was equally removed from the kiln and freely cooled in the kiln. The burning duration of pellets from the basic raw mixtures without addition of SAF or ARM was 15 and 30 minutes for granulometry of maximum $1 \%$ residue on a $90 \mu \mathrm{m}$ sieve and 20 and 40 minutes for granulometry of maximum $1 \%$ residue on 200 
$\mu \mathrm{m}$ sieve at standard firing conditions. At the other cases, the burning time was chosen according to the phase composition development. The burnt clinkers were analyzed by XRD analysis connected with Rietveld computation of quantitative analysis of clinker minerals [18]. The clinker quality was expressed mainly by the content of two principal clinker minerals alite $\mathrm{C}_{3} \mathrm{~S}$ and belite $\mathrm{C}_{2} \mathrm{~S}$. The limit for belite $\mathrm{C}_{2} \mathrm{~S}$ content in the experimental clinker has been chosen on 20 wt. \%. Small amount of the samples did not allow testing the mechanical and physical characteristics of the cements.

Mineralogical composition of SAF and ARM is as follows: AMBM - hydroxylapatite $\mathrm{Ca}_{5}\left(\mathrm{PO}_{4}\right)_{3} \mathrm{OH}$, calcite $\mathrm{CaCO}_{3}$, whitlockite $\mathrm{Ca}_{3}\left(\mathrm{PO}_{4}\right)_{2}\left(\mathrm{C}_{3} \mathrm{P}\right)$, sodium calcium phosphate $\beta$ $\mathrm{NaCaPO}_{4}$, quartz $\mathrm{SiO}_{2}$, sylvite $\mathrm{KCl}$; ASS - quartz $\mathrm{SiO}_{2}$, dolomite $\mathrm{CaMg}\left(\mathrm{CO}_{3}\right)_{2}$, calcium phosphate $\mathrm{Ca}_{3}\left(\mathrm{PO}_{4}\right)_{2}\left(\mathrm{C}_{3} \mathrm{P}\right)$, maghemite $\mathrm{Fe}_{2} \mathrm{O}_{3}$, hematite $\mathrm{Fe}_{2} \mathrm{O}_{3}$, calcium iron oxide $\mathrm{C}_{2} \mathrm{~F}$, anhydrite $\mathrm{CaSO}_{4}$, gehlenite $\mathrm{C}_{2} \mathrm{AS}$, brownmillerite $\mathrm{C}_{4} \mathrm{AF}$; APS - calcite $\mathrm{CaCO}_{3}$, quartz $\mathrm{SiO}_{2}$, free lime $\mathrm{CaO}$, portlandite $\mathrm{Ca}(\mathrm{OH})_{2}$, anhydrite $\mathrm{CaSO}_{4}$; GBS - glassy matrix with very small amount of melilite - solid solution of gehlenite $\mathrm{C}_{2} \mathrm{AS}$ and akermanite $\mathrm{C}_{2} \mathrm{MS}_{2}$ crystals identified; $\mathrm{ABS}$ - melilite - solid solution of gehlenite $\mathrm{C}_{2} \mathrm{AS}$ and akermanite $\mathrm{C}_{2} \mathrm{MS}_{2}$, brownmillerite $\mathrm{C}_{4} \mathrm{AF}$, quartz $\mathrm{SiO}_{2}$; DSS - wüstite $\mathrm{FeO}$, brownmillerite $\mathrm{C}_{4} \mathrm{AF}$, free lime $\mathrm{CaO}$, portlandite $\mathrm{Ca}(\mathrm{OH})_{2}$, belite $\beta-\mathrm{C}_{2} \mathrm{~S}$, quartz $\mathrm{SiO}_{2}$; FCFA - quartz $\mathrm{SiO}_{2}$, anhydrite $\mathrm{CaSO}_{4}$, free lime $\mathrm{CaO}$, anorthite $\mathrm{CAS}_{2}$, hematite $\mathrm{Fe}_{2} \mathrm{O}_{3}$, magnetite $\mathrm{Fe}_{3} \mathrm{O}_{4} ; \mathrm{WG}$ - fully glassy phase.

\section{Results and discussion}

\subsection{The firing of common industrial cement raw mixture}

The maximal possible alite $\mathrm{C}_{3} \mathrm{~S}$ content reachable by the firing of the used common industrial cement raw mixture (RM) has been tested on the 2 basic raw mixtures - with granulometry of maximum $1 \%$ residue on $200 \mu \mathrm{m}$ fired 20 minutes (RM1) and 40 minutes (RM2) and with granulometry of maximum $1 \%$ residue on a $90 \mu \mathrm{m}$ sieve fired 15 minutes (RM3) and 30 minutes (RM4). The additional grinding below $90 \mu \mathrm{m}$ has been applied to eliminate the coarse particles influence on the rate of clinker phase development as much as possible and to increase the reactivity of raw mixtures.

Table 2: The phase composition of clinkers prepared from industrial cement raw mixtures.

\begin{tabular}{|l|c|c|c|c|c|c|c|c|c|c|}
\hline wt. \% & $\mathrm{C}_{3} \mathrm{~S}$ & $\mathrm{C}_{2} \mathrm{~S}$ & $\mathrm{C}_{3} \mathrm{~A} \mathrm{c}$ & $\mathrm{C}_{3} \mathrm{~A} \mathrm{o}$ & $\mathrm{C}_{4} \mathrm{AF}$ & $\mathrm{C}_{\text {free }}$ & $\mathrm{M}$ & $\mathrm{Q}$ & $\mathrm{K}_{2} \mathrm{SO}_{4}$ & $\mathrm{CH}$ \\
\hline $\mathrm{RM} 1$ & 64.89 & 17.83 & 4.33 & 0.00 & 10.47 & 1.57 & 0.36 & 0.37 & 0.00 & 0.18 \\
RM 2 & 72.17 & 14.10 & 2.44 & 0.00 & 9.43 & 0.69 & 0.53 & 0.36 & 0.00 & 0.29 \\
$\mathrm{RM} \mathrm{3}$ & 73.02 & 10.27 & 5.69 & 0.51 & 9.53 & 0.40 & 0.30 & 0.19 & 0.00 & 0.11 \\
RM 4 & 77.55 & 7.94 & 3.69 & 0.00 & 9.67 & 0.09 & 0.55 & 0.52 & 0.00 & 0.00 \\
\hline
\end{tabular}

The granulometry of the raw mixture influences the reactivity i.e. reaching maximal possible alite $\mathrm{C}_{3} \mathrm{~S}$ content in the cement clinker during time unit in a great extent. The maximal alite $\mathrm{C}_{3} \mathrm{~S}$ content 77.55 wt. \% with minimal reached belite content $\mathrm{C}_{2} \mathrm{~S} 7.94$ wt. \% has been achieved at raw mixture RM4. However, the granulometry of the common industrial cement raw mixtures is in the range about $1 \%$ residue on $200 \mu \mathrm{m}$ and so the alite $\mathrm{C}_{3} \mathrm{~S}$ content 72.17 wt. \% with belite content $\mathrm{C}_{2} \mathrm{~S} 14.10 \mathrm{wt}$ \% $\%$ is decisive for practical industrial applications. The 
limiting belite $\mathrm{C}_{2} \mathrm{~S}$ content in the fired experimental clinkers chosen on the level $20 \mathrm{wt} \%$ has not been exceeded in all cases. Therefore all alternative fuel ashes and raw materials rich in $\mathrm{SiO}_{2}$ content together with low $\mathrm{CaO}$ content increase the belite $\mathrm{C}_{2} \mathrm{~S}$ content in the clinker. The content of interstitial matter consisting of $\mathrm{C}_{3} \mathrm{~A}$ and $\mathrm{C}_{4} \mathrm{AF}$, which forms liquid phase - melt during firing, has been increased by increasing reactivity but it has been decreased with prolonged firing time. The content of cubic $\mathrm{C}_{3} \mathrm{~A}$ in comparison with content of orthorhombic one has been strongly predominant due to very low alkalis in the used common industrial cement raw mixture. At low amount of alkalis available, cubic $\mathrm{C}_{3} \mathrm{~A}$ is formed having moderate reactivity. On the other hand, at high amount of alkalis available, orthorhombic $\mathrm{C}_{3} \mathrm{~A}$ is formed having enhanced reactivity. Amount of reactive orthorhombic $\mathrm{C}_{3} \mathrm{~A}$ also decreases with increasing degree of sulphatisation in the clinker, i.e. with rising sulphur content in the added alternative fuel ashes and raw materials. The degree of sulphatisation of alkalis in the clinker can be seen on the base of arcanite $\mathrm{K}_{2} \mathrm{SO}_{4}$ content, however its content is also very strongly dependant on the evaporation at high temperatures. The content of unbound quartz $\mathrm{SiO}_{2}(\mathrm{Q})$ in the clinker (cement insoluble residue comprises mainly unbound quartz $\mathrm{SiO}_{2}$ ) represent the part of raw mixture with the lowest reactivity consisting of large particles of quartz and hornfels, the influence of which can be diminished by additional grinding under 45 $\mu \mathrm{m}$, where the mineralogical effect is suppressed in a great extent. The content of free lime $\mathrm{C}_{\text {free }}$ has been decreasing with rising reactivity of raw mixture as well as the duration of firing time and not exceeded the limiting value $2.5 \mathrm{wt}$. \%, after which the clinker can be volumetrically unstable with undesired expansion. Portlandite $\mathrm{Ca}(\mathrm{OH})_{2}(\mathrm{CH})$ in clinker is formed by hydration of very active free lime $\mathrm{C}_{\text {free }}$ with air humidity. With decreasing free lime $\mathrm{C}_{\text {free }}$ content, the alite $\mathrm{C}_{3} \mathrm{~S}$ content has been increased and belite $\mathrm{C}_{2} \mathrm{~S}$ content has been decreased, as well.

\subsection{Addition of granulated blast-furnace slag}

The experimental mixture (EM) consisting of $5 \mathrm{wt}$. \% fine granulated blastfurnace slag (GBS) and 95 wt. \% industrial cement raw mixture (RM) has been studied on the base of 2 basic experimental mixtures having been fired at $1430{ }^{\circ} \mathrm{C}$ - with granulometry of maximum $1 \%$ residue on $200 \mu \mathrm{m}$ fired 20 minutes (EM1) and 40 minutes (EM2) and with granulometry of maximum $1 \%$ residue on a $90 \mu \mathrm{m}$ sieve fired 15 minutes (EM3) and 30 minutes (EM4).

Table 3: The phase composition of clinkers prepared from EM containing GBS and RM.

\begin{tabular}{|l|c|c|c|c|c|c|c|c|c|c|}
\hline wt. \% & $\mathrm{C}_{3} \mathrm{~S}$ & $\mathrm{C}_{2} \mathrm{~S}$ & $\mathrm{C}_{3} \mathrm{~A}$ c & $\mathrm{C}_{3} \mathrm{~A} \mathrm{o}$ & $\mathrm{C}_{4} \mathrm{AF}$ & $\mathrm{C}_{\text {free }}$ & $\mathrm{M}$ & $\mathrm{Q}$ & $\mathrm{K}_{2} \mathrm{SO}_{4}$ & $\mathrm{CH}$ \\
\hline EM 1 & 58.02 & 24.93 & 2.28 & 1.15 & 12.30 & 0.22 & 0.68 & 0.13 & 0.00 & 0.28 \\
EM 2 & 58.85 & 24.88 & 2.28 & 0.49 & 12.60 & 0.10 & 0.49 & 0.18 & 0.00 & 0.14 \\
EM 3 & 60.21 & 22.43 & 3.30 & 0.80 & 12.20 & 0.08 & 0.51 & 0.03 & 0.04 & 0.38 \\
EM 4 & 60.54 & 22.90 & 2.63 & 0.51 & 12.54 & 0.00 & 0.49 & 0.06 & 0.00 & 0.33 \\
\hline
\end{tabular}

From the results in Table 3 it can be seen, that the addition of 5 wt. \% GBS to the industrial cement RM has undesirably increased the belite $\mathrm{C}_{2} \mathrm{~S}$ content in the clinker over the limit 20 wt. \% with appropriate alite $\mathrm{C}_{3} \mathrm{~S}$ content decrease. The highest belite $\mathrm{C}_{2} \mathrm{~S}$ content $24.93 \mathrm{wt}$. \% has been achieved at experimental mixture EM 1, which decreased by 2 wt. \% with increasing of reactivity and firing time, together with adequate increase in alite $\mathrm{C}_{3} \mathrm{~S}$ content. The content 
of cubic $\mathrm{C}_{3} \mathrm{~A}$ has been decreased with simultaneous orthorhombic $\mathrm{C}_{3} \mathrm{~A}$ content increase in comparison with the pure raw mixture. The low content of free lime $\mathrm{C}_{\text {free }}$ proofs the mineralized effect of fine granulated blastfurnace slag on clinker phases development. GBS is a suitable alternative raw material with recommended addition maximal $4 \mathrm{wt}$. \% that does not exceed the limit 20 wt. $\%$ belite $\mathrm{C}_{2} \mathrm{~S}$ content in the clinker.

\subsection{Addition of air cooled blast-furnace slag}

The experimental mixture (EM) consisting of $5 \mathrm{wt} . \%$ fine air cooled blast-furnace slag (ABS) and 95 wt. \% industrial cement raw mixture (RM) has been studied on the base of 2 basic experimental mixtures having been fired at $1430{ }^{\circ} \mathrm{C}$ - with granulometry of maximum $1 \%$ residue on $200 \mu \mathrm{m}$ fired 20 minutes (EM5) and 40 minutes (EM6) and with granulometry of maximum $1 \%$ residue on a $90 \mu \mathrm{m}$ sieve fired 15 minutes (EM7) and 30 minutes (EM8).

Table 4: The phase composition of clinkers prepared from EM containing ABS and RM.

\begin{tabular}{|c|c|c|c|c|c|c|c|c|c|c|}
\hline wt. \% & $\mathrm{C}_{3} \mathrm{~S}$ & $\mathrm{C}_{2} \mathrm{~S}$ & $\mathrm{C}_{3} \mathrm{~A}$ c & $\mathrm{C}_{3} \mathrm{~A}$ o & $\mathrm{C}_{4} \mathrm{AF}$ & $\mathrm{C}_{\text {free }}$ & $\mathrm{M}$ & $\mathrm{Q}$ & $\mathrm{K}_{2} \mathrm{SO}_{4}$ & $\mathrm{CH}$ \\
\hline EM5 & 58.29 & 24.66 & 2.83 & 0.32 & 12.07 & 0.61 & 0.63 & 0.35 & 0.00 & 0.24 \\
EM6 & 59.11 & 23.77 & 1.81 & 0.95 & 13.47 & 0.09 & 0.48 & 0.16 & 0.00 & 0.16 \\
EM7 & 58.09 & 24.47 & 2.77 & 0.93 & 13.03 & 0.00 & 0.39 & 0.17 & 0.05 & 0.11 \\
EM8 & 46.85 & 32.75 & 4.61 & 1.70 & 13.18 & 0.00 & 0.29 & 0.36 & 0.16 & 0.10 \\
\hline
\end{tabular}

From the results in Table 4 it can be seen, that the addition of $5 \mathrm{wt}$. $\%$ fine ABS to the industrial cement RM also has undesirably increased the belite $\mathrm{C}_{2} \mathrm{~S}$ content in the clinker over the limit $20 \mathrm{wt} . \%$ with appropriate alite $\mathrm{C}_{3} \mathrm{~S}$ content decrease like in the case of GBS. Both slags have relatively the same chemical composition, but very different mineralogical composition due to their cooling regime. The highest belite $\mathrm{C}_{2} \mathrm{~S}$ content $32.75 \mathrm{wt} \%$ has been achieved in the case of experimental mixture with granulometry of maximum $1 \%$ residue on a $90 \mu \mathrm{m}$ sieve fired 30 minutes (EM8), simultaneously with the lowest alite $\mathrm{C}_{3} \mathrm{~S}$ content 46.85 wt. \%, which is unacceptable values. The high $\mathrm{SiO}_{2}$ content of fully crystallized ABS, mainly in the form of quartz $\mathrm{SiO}_{2}$, has negatively proved on the $\mathrm{C}_{3} \mathrm{~S} / \mathrm{C}_{2} \mathrm{~S}$ ratio in a great extent, in contrary to the high $\mathrm{SiO}_{2}$ content of practically fully glassy GBS, where the glassy phase had a little intensifying effect on clinker forming reactions. The great decrease of alite $\mathrm{C}_{3} \mathrm{~S}$ content in experimental mixture EM8 has been connected with the slight increase in cubic $\mathrm{C}_{3} \mathrm{~A}$ as well as orthorhombic $\mathrm{C}_{3} \mathrm{~A}$ content. Therefore $\mathrm{ABS}$ is not so appropriate alternative raw material than GBS, however it can be recommended the maximal addition $4.2 \mathrm{wt} \%$ of ABS to the cement RM with the granulometry of $1 \%$ residue on $200 \mu \mathrm{m}$ being fired for 40 minutes, not to exceed the limit $20 \mathrm{wt}$. $\%$ belite $\mathrm{C}_{2} \mathrm{~S}$ content in the clinker. In this case, ABS can be stated as a suitable alternative raw material.

\subsection{Addition of demetallized steel slag}

The experimental mixture (EM) consisting of $5 \mathrm{wt}$ \% fine demetallized steel slag (DSS) and 95 wt. \% industrial cement raw mixture (RM) has been studied on the base of 2 basic experimental mixtures having been fired at $1430{ }^{\circ} \mathrm{C}$ - with granulometry of maximum $1 \%$ 
residue on $200 \mu \mathrm{m}$ fired 20 minutes (EM9) and 40 minutes (EM10) and with granulometry of maximum $1 \%$ residue on a $90 \mu \mathrm{m}$ sieve fired 15 minutes (EM11) and 30 minutes (EM12).

Table 5: The phase composition of clinkers prepared from EM containing DSS and RM.

\begin{tabular}{|c|c|c|c|c|c|c|c|c|c|c|}
\hline wt. \% & $\mathrm{C}_{3} \mathrm{~S}$ & $\mathrm{C}_{2} \mathrm{~S}$ & $\mathrm{C}_{3} \mathrm{~A} \mathrm{c}$ & $\mathrm{C}_{3} \mathrm{~A} \mathrm{o}$ & $\mathrm{C}_{4} \mathrm{AF}$ & $\mathrm{C}_{\text {free }}$ & $\mathrm{M}$ & $\mathrm{Q}$ & $\mathrm{K}_{2} \mathrm{SO}_{4}$ & $\mathrm{CH}$ \\
\hline EM9 & 74.49 & 5.58 & 0.05 & 0.00 & 18.22 & 0.40 & 0.47 & 0.63 & 0.00 & 0.16 \\
EM10 & 70.20 & 9.02 & 0.64 & 0.00 & 19.10 & 0.01 & 0.58 & 0.32 & 0.00 & 0.12 \\
EM11 & 74.66 & 5.25 & 0.36 & 0.31 & 18.46 & 0.00 & 0.40 & 0.51 & 0.04 & 0.00 \\
EM12 & 68.76 & 8.40 & 1.07 & 0.01 & 21.26 & 0.00 & 0.14 & 0.36 & 0.00 & 0.00 \\
\hline
\end{tabular}

The very high $\mathrm{Fe}_{2} \mathrm{O}_{3}$ amount in DSS compared to blastfurnace slags has caused the increase in $\mathrm{C}_{4} \mathrm{AF}$ content over $18 \mathrm{wt}$. \% and on the other hand the decrease of $\mathrm{C}_{3} \mathrm{~A}$ content down near to zero value. The high ratio of $\mathrm{CaO} / \mathrm{SiO}_{2}$ predominantly favoured formation of high amount of alite $\mathrm{C}_{3} \mathrm{~S}$ in the clinker, the content of which has decreased in a little extent by firing time on behalf of belite $\mathrm{C}_{2} \mathrm{~S}$ content, which has increased from approx. $5 \mathrm{wt}$. \% up to maximal 9.02 wt. \% in experimental mixture EM10 (Table 5). The low content of free lime $\mathrm{C}_{\text {free }}$ proofs the intensifying effect of fine DSS on clinker phases development. After adding $5 \mathrm{wt} \%$ fine DSS, the interstitial matter practically consists of $\mathrm{C}_{4} \mathrm{AF}$ phase with very low $\mathrm{C}_{3} \mathrm{~A}$ content, which predominates the utilization of DSS for a synthesis of special clinkers with low $\mathrm{C}_{3} \mathrm{~A}$ content suitable for the production of high sulphate resistant portland cements CEM I - SR.

\subsection{Addition of fluidized bed combustion fly ash}

The experimental mixtures (EM) consisting of $2.5 \mathrm{wt}$. \% fluidized bed combustion fly ash (FCFA) and $97.5 \mathrm{wt} . \%$ industrial cement raw mixture (RM) marked as (EM13) and 5 wt. \% fine FCFA and 95 wt. \% RM marked as (EM14) with granulometry of maximum $1 \%$ residue on $200 \mu \mathrm{m}$ were fired at $1430{ }^{\circ} \mathrm{C}$ for 30 minutes in order not to loss excessively sulphates by evaporation. The results are given in Table 6. The firing of finer RM with granulometry of maximum $1 \%$ residue on a $90 \mu \mathrm{m}$ sieve with increased reactivity has not been realized due to very strong mineralizing effect of sulphates on clinkering process.

Table 6: The phase composition of clinkers prepared from EM containing FCFA and RM.

\begin{tabular}{|c|c|c|c|c|c|c|c|c|c|c|c|}
\hline wt. \% & $\mathrm{C}_{3} \mathrm{~S}$ & $\mathrm{C}_{2} \mathrm{~S}$ & $\mathrm{C}_{3} \mathrm{Ac}$ & $\mathrm{C}_{3} \mathrm{Ao}$ & $\mathrm{C}_{4} \mathrm{AF}$ & $\mathrm{C}_{\text {free }}$ & $\mathrm{M}$ & $\mathrm{Q}$ & $\mathrm{K}_{2} \mathrm{SO}_{4}$ & $\mathrm{CH}$ & $\mathrm{CaSO}_{4}$ \\
\hline EM13 & 67.06 & 15.22 & 5.10 & 0.29 & 10.60 & 0.87 & 0.42 & 0.12 & 0.00 & 0.25 & 0.04 \\
EM14 & 45.88 & 29.34 & 9.35 & 1.66 & 4.90 & 2.45 & 0.67 & 0.43 & 0.00 & 0.01 & 5.27 \\
\hline
\end{tabular}

Very high amount of sulphates $\mathrm{SO}_{3}$ in the form of anhydrite $\mathrm{CaSO}_{4}$ in FCFA compared to the other tested materials has given the reason for an assumption of formation sulphate containing compounds such as ye'elimite (Klein's compound) phase $3 \mathrm{CaO} \cdot 3 \mathrm{Al}_{2} \mathrm{O}_{3} \cdot \mathrm{CaSO}_{4}$ being formed by reaction of calcium aluminates with anhydrite. However no ye'elimite compound has been found on XRD pattern, only unreacted anhydrite $\mathrm{CaSO}_{4}$ has been clearly identified. The 2.5 wt. \% addition of FCFA to the industrial cement raw mixture has resulted in the clinker with usual phase composition. However, 5 wt. \% addition of FCFA has provided the clinker with very high amount of belite $\mathrm{C}_{2} \mathrm{~S} 29.34$ wt. \% together with low alite $\mathrm{C}_{3} \mathrm{~S}$ content on the level 
45.88 wt. $\%$. The $5 \mathrm{wt}$. \% addition also has changed the composition of interstitial matrix. The amount of cubic $\mathrm{C}_{3} \mathrm{~A}$ has been increased up to $9.35 \mathrm{wt}$. \% value while $\mathrm{C}_{4} \mathrm{AF}$ content has been decreased down to $4.90 \mathrm{wt}$. \%. There has been an inappropriate increase in $\mathrm{C}_{\text {free }}$ content on the level of $2.45 \mathrm{wt} . \%$, which can cause undesired expansion of volumetrically unstable clinker. The 5 wt. \% addition of FCFA is fully unacceptable. Therefore, FCFA appears to be worse alternative raw material for cement clinker burning with less potential utilization in the cement industry and with maximal addition $3.41 \mathrm{wt} . \%$, which forms undesired $\mathrm{CaSO}_{4}$.

\subsection{Addition of powdered waste glass}

The experimental mixtures (EM) consisting of different amounts of fine powdered waste glass (WG) added to the industrial cement raw mixture (RM) with granulometry of maximum $1 \%$ residue on $200 \mu \mathrm{m}$ have been studied by firing 3 basic experimental mixtures at $1430{ }^{\circ} \mathrm{C}$ for 20 and 40 minutes: experimental mixtures consisting of 1 wt. \% fine powdered WG and 99 wt. \% industrial cement $\mathrm{RM}$ fired at $1430{ }^{\circ} \mathrm{C}$ for 20 (EM15) and 40 minutes (EM16); experimental mixtures consisting of $3 \mathrm{wt}$ \% fine powdered $\mathrm{WG}$ and $97 \mathrm{wt}$ \% industrial cement RM fired at $1430{ }^{\circ} \mathrm{C}$ for 20 (EM17) and 40 minutes (EM18); experimental mixtures consisting of $5 \mathrm{wt}$ \% $\%$ fine powdered WG and $95 \mathrm{wt} \% \%$ industrial cement RM fired at $1430{ }^{\circ} \mathrm{C}$ for 20 (EM19) and 40 minutes (EM20).

Table 7: The phase composition of clinkers prepared from EM containing WG and RM.

\begin{tabular}{|c|c|c|c|c|c|c|c|c|c|c|}
\hline wt. \% & $\mathrm{C}_{3} \mathrm{~S}$ & $\mathrm{C}_{2} \mathrm{~S}$ & $\mathrm{C}_{3} \mathrm{~A} \mathrm{c}$ & $\mathrm{C}_{3} \mathrm{~A}$ o & $\mathrm{C}_{4} \mathrm{AF}$ & $\mathrm{C}_{\text {free }}$ & $\mathrm{M}$ & $\mathrm{Q}$ & $\mathrm{K}_{2} \mathrm{SO}_{4}$ & $\mathrm{CH}$ \\
\hline EM15 & 60.69 & 21.32 & 5.44 & 1.42 & 8.92 & 1.50 & 0.28 & 0.20 & 0.05 & 0.18 \\
EM16 & 65.49 & 17.27 & 4.72 & 1.20 & 10.06 & 0.82 & 0.21 & 0.20 & 0.00 & 0.03 \\
EM17 & 48.67 & 29.35 & 7.83 & 4.00 & 8.18 & 0.59 & 0.11 & 0.39 & 0.29 & 0.59 \\
EM18 & 51.77 & 28.43 & 5.77 & 3.54 & 9.32 & 0.13 & 0.33 & 0.22 & 0.00 & 0.49 \\
EM19 & 41.53 & 33.93 & 9.96 & 5.72 & 7.31 & 0.10 & 0.07 & 0.33 & 0.30 & 0.73 \\
EM20 & 35.53 & 42.17 & 7.53 & 4.45 & 9.16 & 0.11 & 0.20 & 0.38 & 0.02 & 0.44 \\
\hline
\end{tabular}

Very high amount of $\mathrm{SiO}_{2}$ compared to low $\mathrm{CaO}$ content in the powdered $\mathrm{WG}$ predestines the use of this alternative raw material for a production of special belite clinkers with low development of strengths according and low heat of hydration in accordance with American standard ASTM C 150 [17]. Already 1 wt. \% addition of fine powdered WG has increased the belite $\mathrm{C}_{2} \mathrm{~S}$ content in the clinker over limit $20 \mathrm{wt}$. \%. With increasing addition of fine powdered WG, the belite $\mathrm{C}_{2} \mathrm{~S}$ content has been gradually increased at the expense of alite $\mathrm{C}_{3} \mathrm{~S}$ content decreasing. At $5 \mathrm{wt}$ \% addition of fine powdered WG in experimental mixture EM20, the belite $\mathrm{C}_{2} \mathrm{~S}$ content reached twice the limiting amount $42.17 \mathrm{wt} . \% \mathrm{C}_{2} \mathrm{~S}$ at the level of alite $\mathrm{C}_{3} \mathrm{~S}$ content 35.53 wt. \%, which are not acceptable values. Very high amount of $\mathrm{Na}_{2} \mathrm{O}$ in WG promotes increased formation of reactive orthorhombic $\mathrm{C}_{3} \mathrm{~A}$. With the increasing of addition of fine powdered WG, the content of reactive orthorhombic $\mathrm{C}_{3} \mathrm{~A}$ has been gradually increased as well as the content of cubic $\mathrm{C}_{3} \mathrm{~A}$, the contents of which have decreased in a little extent with burning time on account of the increase of $\mathrm{C}_{4} \mathrm{AF}$ in a little extent as well. The low content of free lime $\mathrm{C}_{\text {free }}$ proofs the intensifying effect of fine powdered WG on clinker phase development. $\mathrm{WG}$ is the worst alternative raw material with addition only $1.16 \mathrm{wt}$ \% possible. 


\subsection{Addition of meat-bone meal ash}

The experimental mixtures (EM) consisting of $4 \mathrm{wt}$. \% fine meat-bone meal ash (AMBM) i.e. containing 1.5 wt. $\% \mathrm{P}_{2} \mathrm{O}_{5}$ and 96 wt. \% industrial cement raw mixture (RM) marked as (EM21) and 8 wt. \% meat-bone meal ash (AMBM) i.e. containing $3.0 \mathrm{wt} . \% \mathrm{P}_{2} \mathrm{O}_{5}$ and $92 \mathrm{wt}$. $\%$ industrial cement raw mixture (RM) marked as (EM22) with granulometry of maximum 1 $\%$ residue on $200 \mu \mathrm{m}$ were fired at $1430{ }^{\circ} \mathrm{C}$ for 40 minutes.

Table 8: The phase composition of clinkers prepared from EM containing AMBM and RM.

\begin{tabular}{|c|c|c|c|c|c|c|c|c|c|c|}
\hline wt. \% & $\mathrm{C}_{3} \mathrm{~S}$ & $\mathrm{C}_{2} \mathrm{~S}$ & $\mathrm{C}_{3} \mathrm{~A} \mathrm{c}$ & $\mathrm{C}_{3} \mathrm{~A} \mathrm{o}$ & $\mathrm{C}_{4} \mathrm{AF}$ & $\mathrm{C}_{\text {free }}$ & $\mathrm{M}$ & $\mathrm{Q}$ & $\mathrm{K}_{2} \mathrm{SO}_{4}$ & $\mathrm{CH}$ \\
\hline EM21 & 52.61 & 28.94 & 3.30 & 2.56 & 10.22 & 1.20 & 0.21 & 0.10 & 0.05 & 0.81 \\
EM22 & 34.59 & 42.06 & 5.22 & 4.96 & 8.03 & 2.98 & 0.15 & 0.00 & 0.13 & 1.88 \\
\hline
\end{tabular}

In practice, as long as phosphate $\mathrm{P}_{2} \mathrm{O}_{5}$ contents are less than $1 \mathrm{wt} . \mathrm{\%}$ in cement clinker, no detrimental effects on product quality are found $[15,16]$. However, phosphates $\mathrm{P}_{2} \mathrm{O}_{5}$ being present in AMBM has very strong retarding effect on alite $\mathrm{C}_{3} \mathrm{~S}$ formation reaching the minimal value 34.59 wt. \% at simultaneous maximal belite $\mathrm{C}_{2} \mathrm{~S}$ content of $42.06 \mathrm{wt}$. \% at the level of 3 wt. $\% \mathrm{P}_{2} \mathrm{O}_{5}$ in experimental mixture (EM22). This extreme case with high $\mathrm{P}_{2} \mathrm{O}_{5}$ amount is connected also with high amount of free lime $\mathrm{C}_{\text {free }} 2.98 \mathrm{wt} . \%$ and simultaneously high content of hydrated portlandite $\mathrm{Ca}(\mathrm{OH})_{2} 1.88$ wt. \% in the clinker, which makes the clinker volumetrically unstable with undesired expansion. Higher amount of alkalis $\mathrm{Na}_{2} \mathrm{O}$ and $\mathrm{K}_{2} \mathrm{O}$ in the powdered AMBM has promoted the increased formation of reactive orthorhombic $\mathrm{C}_{3} \mathrm{~A}$. MBM can be evaluated as moderately suitable alternative fuels which can be added in the amounts of $2.8 \mathrm{wt} \%$ addition of AMBM to the cement RM, which causes the increase $\mathrm{P}_{2} \mathrm{O}_{5}$ content in the clinker on the level of $1.05 \mathrm{wt} . \%$.

\subsection{Addition of sewage sludge ash from waste water plants}

The experimental mixture (EM) consisting of $5 \mathrm{wt}$ \% fine ash of sewage sludge from waste water plants (ASS) and 95 wt. \% industrial cement raw mixture (RM) has been studied on the base of 2 basic experimental mixtures having been fired at $1430{ }^{\circ} \mathrm{C}$ - with granulometry of maximum $1 \%$ residue on $200 \mu \mathrm{m}$ fired 20 minutes (EM23) and 40 minutes (EM24) and with granulometry of maximum $1 \%$ residue on a $90 \mu \mathrm{m}$ sieve fired 15 minutes (EM25) and 30 minutes (EM26).

Table 9: The phase composition of clinkers prepared from EM containing ASS and RM.

\begin{tabular}{|c|c|c|c|c|c|c|c|c|c|c|}
\hline wt. \% & $\mathrm{C}_{3} \mathrm{~S}$ & $\mathrm{C}_{2} \mathrm{~S}$ & $\mathrm{C}_{3} \mathrm{~A} \mathrm{c}$ & $\mathrm{C}_{3} \mathrm{~A} \mathrm{o}$ & $\mathrm{C}_{4} \mathrm{AF}$ & $\mathrm{C}_{\text {free }}$ & $\mathrm{M}$ & $\mathrm{Q}$ & $\mathrm{K}_{2} \mathrm{SO}_{4}$ & $\mathrm{CH}$ \\
\hline EM23 & 48.32 & 25.01 & 4.17 & 4.58 & 16.80 & 0.06 & 0.12 & 0.51 & 0.15 & 0.29 \\
EM24 & 46.63 & 27.48 & 5.14 & 2.94 & 16.89 & 0.04 & 0.08 & 0.29 & 0.09 & 0.42 \\
EM25 & 52.52 & 22.04 & 4.57 & 4.38 & 15.71 & 0.00 & 0.00 & 0.38 & 0.10 & 0.30 \\
EM26 & 44.47 & 30.20 & 4.26 & 3.77 & 16.42 & 0.05 & 0.12 & 0.16 & 0.11 & 0.45 \\
\hline
\end{tabular}

The additions of 5 wt. \% fine ASS having high $\mathrm{SiO}_{2} / \mathrm{CaO}$ ratio to cement raw mixture has possessed strong retarding effect on alite $\mathrm{C}_{3} \mathrm{~S}$ formation reaching the minimal value $44.47 \mathrm{wt}$. 
$\%$ at simultaneous maximal belite $\mathrm{C}_{2} \mathrm{~S}$ content $30.20 \mathrm{wt}$ \% (EM26). The retarding effect has been supported also by increased $\mathrm{P}_{2} \mathrm{O}_{5}$ content on the level $5.64 \mathrm{wt}$ \% from the detergents from households. The amount of alite $\mathrm{C}_{3} \mathrm{~S}$ has been decrease with firing time on behalf of increasing belite $\mathrm{C}_{2} \mathrm{~S}$ content in the clinker. The high amount of $\mathrm{Al}_{2} \mathrm{O}_{3}$ has promoted the formation of orthorhombic $\mathrm{C}_{3} \mathrm{~A}$. The amount of total interstitial matter consisting of $\mathrm{C}_{3} \mathrm{~A}$ and $\mathrm{C}_{4} \mathrm{AF}$ has been increased on the levels more than $24 \mathrm{wt} . \%$, which is the highest value from all alternative fuel ashes and alternative having been added to experimental mixtures. The high amount of interstitial matter formed a high amount of liquid phase - melt during firing, which has promoted the clinker phase forming reactions and so very low amount of free lime $\mathrm{C}_{\text {free }}$ and very low portlandite $\mathrm{Ca}(\mathrm{OH})_{2}$ content in the clinker. Sewage sludge can be evaluated as moderately suitable alternative fuels which can be added in the amounts of $3.64 \mathrm{wt}$. \% addition of ASS to the cement raw mixture.

\subsection{Addition of paper sludge ash}

The experimental mixture (EM) consisting of $5 \mathrm{wt}$. \% fine ash of paper sludge (APS) and 95 wt. \% industrial cement raw mixture (RM) with granulometry of maximum $1 \%$ residue on $200 \mu \mathrm{m}(\mathrm{EM} 27)$ and with granulometry of maximum $1 \%$ residue on a $90 \mu \mathrm{m}$ sieve (EM28) fired at $1430{ }^{\circ} \mathrm{C}$ for 40 minutes.

Table 10: The phase composition of clinkers prepared from EM containing APS and RM.

\begin{tabular}{|c|c|c|c|c|c|c|c|c|c|c|}
\hline wt. \% & $\mathrm{C}_{3} \mathrm{~S}$ & $\mathrm{C}_{2} \mathrm{~S}$ & $\mathrm{C}_{3} \mathrm{~A} \mathrm{c}$ & $\mathrm{C}_{3} \mathrm{~A}$ o & $\mathrm{C}_{4} \mathrm{AF}$ & $\mathrm{C}_{\text {free }}$ & $\mathrm{M}$ & $\mathrm{Q}$ & $\mathrm{K}_{2} \mathrm{SO}_{4}$ & $\mathrm{CH}$ \\
\hline EM27 & 57.24 & 26.63 & 2.67 & 0.37 & 12.38 & 0.00 & 0.15 & 0.32 & 0.00 & 0.24 \\
EM28 & 51.92 & 31.38 & 1.99 & 0.80 & 13.14 & 0.00 & 0.40 & 0.20 & 0.00 & 0.17 \\
\hline
\end{tabular}

The addition of $5 \mathrm{wt}$ \% fine APS to industrial cement RM has increased the belite $\mathrm{C}_{2} \mathrm{~S}$ content in the clinker over limit $20 \mathrm{wt} . \%$. With increasing reactivity of experimental mixture with additional grinding under $90 \mu \mathrm{m}$, the belite $\mathrm{C}_{2} \mathrm{~S}$ content has been increased on the level $31.38 \mathrm{wt}$. \% at the expense of alite $\mathrm{C}_{3} \mathrm{~S}$ content decreasing to $51.92 \mathrm{wt}$. \%. Higher amount of $\mathrm{Al}_{2} \mathrm{O}_{3}$ in APS has increased orthorhombic $\mathrm{C}_{3} \mathrm{~A}$ content only in small extent, however total $\mathrm{C}_{3} \mathrm{~A}$ content is not so high in comparison with the composition of clinker fired from pure $\mathrm{RM}$, because a part of $\mathrm{Al}_{2} \mathrm{O}_{3}$ has been consumed on $\mathrm{C}_{4} \mathrm{AF}$ formation. The $0.00 \mathrm{wt}$. \% value of $\mathrm{C}_{\text {free }}$ and very low portlandite $\mathrm{Ca}(\mathrm{OH})_{2}$ content proofs the intensifying effect of fine powdered APS on clinker phase development. Paper sludge can be evaluated as moderately suitable alternative fuels which can be added in the amounts of $3.8 \mathrm{wt}$. \% addition of APS to the cement raw mixture.

\section{Conclusion}

All tested alternative fuels and raw materials have possessed a great effect on clinker phases development. High amount of $\mathrm{SiO}_{2}$ increased belite $\mathrm{C}_{2} \mathrm{~S}$ content on account of alite $\mathrm{C}_{3} \mathrm{~S}$. Increased amount of alkalis promoted reactive orthorhombic $\mathrm{C}_{3} \mathrm{~A}$. Meat-bone meal, sewage sludge from sewage treatment plants and paper sludge were evaluated as moderately suitable alternative fuels for production of common Portland clinker. Granulated blastfurnace slag and air 
cooled blastfurnace slag are suitable alternative raw materials for portland clinker. Demetallised steel slag is suitable for production of special sulphate resistant cement clinker. Fluidized bed combustion fly ash and waste glass are the worse alternative raw materials of all.

\section{References}

[1] Schneider M. (2013). Technology Developments in the Cement Industry, In proc. of $7^{\text {th }}$ International VDZ Congress 2013, 25-27 ${ }^{\text {th }}$ September, 2013 (1-6). Düsseldorf Germany.

[2] Oertel M. (2008). The use of alternative fuels and raw materials in Europe, In proc. of ECRA Seminar S08-02 Alternative fuels and raw materials, June 4-5 $5^{\text {th }}, 2008$ (1-12). Setúbal, Portugal.

[3] Oertel M. (2013). Suitable waste fuels for cement production, In proc. of ECRA Seminar S1301 Fuels of the future, 11-12 ${ }^{\text {th }}$ April, 2013 (1-21). Split/Kaštel Sućurac, Croatia.

[4] Schneider M. (2011). $\mathrm{CO}_{2}$-Minderung Weltweite Anforderungen. In proc. of Technisch Wissenschaftliche-Zementtagung, $28^{\text {th }}$ September, 2011 (1-27). Düsseldorf, Germany.

[5] Oertel M. (2008). Alternative fuels and the reduction of $\mathrm{CO}_{2}$ emissions. In proc. of ECRA Seminar S08-02 Alternative fuels and raw materials, June 4-5 ${ }^{\text {th }}, 2008$ (1-23). Setúbal, Portugal.

[6] Martauz P., Strigáč J. \& et al. (2001). Method of disposal of processed organic wastes by incineration in cement rotary kilns, Polish Patent PL 197240 B1.

[7] EN 15357 (2011). Solid recovered fuels, Terminology, definitions and descriptions.

[8] EN 15359 (2011). Solid recovered fuels, Specifications and classes.

[9] EN ISO 16559 (2014). Solid biofuels. Terminology, definitions and descriptions.

[10] EN ISO 17225-1 (2014). Solid biofuels. Fuel specifications and classes, General requirements.

[11] European Parliament and of the Council. (2000). Directive 2000/76/EC of the European Parliament and of the Council of 4 December 2000 on the incineration of waste.

[12] Technische regel RAL-GZ 724 (2012). Sekundärbrennstoffe - Gütesicherung, Deutsches Institut für Gütesicherung und Kennzeichnung e.V.

[13] Böhm M. (2011). Influence of Alternative Fuels and Raw Materials on the Properties of Clinker and Cement. In proc. of ECRA Seminar S10-06 Influence of Alternative Fuels and Raw Materials on the Properties of Clinker and Cement, 9-10 ${ }^{\text {th }}$ November, 2010 (1-75). Beckum, Germany.

[14] Impact of Burning and cooling conditions on clinker quality. (2010). European Cement Research Academy ECRA Newsletter No. 3, (3-4). Düsseldorf, Germany [online] available on: http://www.ecra-online.org/uploads/media/ECRA_Newsletter 3-2010.pdf.

[15] Puntke St. \& Schneider M. (2008). Effects of phosphate on clinker mineralogy and cement properties. Cement International, Volume 6, No. 5, 80-93.

[16] Martauz P. \& Strigáč J. (2011). Co-Combustion Solutions from Slovakia. World Cement, Volume 42, No. 11, 87-93.

[17] American Society for Testing and Materials standard ASTM C 150 - 07. (2007). Specification for Portland Cement.

[18] Paul M. (2005). Application of the Rietveld method in the cement industry. In proc. of Microstructure Analysis in Materials Science, 15-17 $7^{\text {th }}$ June, 2005 (1-3). Freiberg, Germany. 